\title{
Constitutional ring chromosomes and tumour
}

\section{suppressor genes}

\author{
Niels Tommerup, Ragnhild Lothe
}

\begin{abstract}
The types of malignancy reported in carriers of constitutional ring chromosomes $r(11), r(13)$, and $r(22)$ are concordant with the chromosomal assignment of tumour suppressor loci associated with Wilms' tumour, retinoblastoma, and meningioma. It is suggested that the somatic instability of ring chromosomes may play a role in this association and that constitutional ring chromosomes may be a source for mapping of tumour suppressor loci with the potential for covering most or all of the human genome. The hypothesis predicts the presence of a locus on chromosome 10 associated with follicular carcinoma of the thyroid, in line with previous cytogenetic findings of rearrangements involving chromosome 10 in thyroid tumours, and a locus on chromosome 22 associated with testicular cancer. Development of neurofibromatoses (NF) that do not fulfil the clinical criteria of neurofibromatosis type 2 (NF2) in carriers with $\mathbf{r}(22)$ suggests either the presence of an additional NF locus on chromosome 22 or that ring chromosome mediated predisposition to somatic mutation of a specific tumour suppressor may be associated with atypical development of features usually associated with germline mutations. (f Med Genet 1992;29:879-82)
\end{abstract}

Homozygotic loss of function of specific growth suppression genes ${ }^{1}$ may form the biological basis for a two mutation theory of tumour initiation..$^{23}$ In carriers of a germline mutation affecting one allele of a tumour suppressor gene, a second somatic mutation involving the other allele may initiate the tumorigenic process in susceptible cell types. Since the number of potential target cells may be large, carriers of such germline mutations frequently develop multifocal or bilateral tumours or both.

In some cases the germline mutation may present as a cytogenetically visible constitutional chromosome rearrangement. In the prototype of inherited tumours, retinoblastoma (RB1), chromosome deletions and translocations involving the RB1 locus at $13 \mathrm{q} 14$ may be observed in up to $10 \%$ of cases. ${ }^{4}$ In some cases, somatic mosaicism for a visible chromosome deletion of 13q14 appears to be responsible for predisposition to $\mathrm{RB} 1.5$

In the present report we have focused on the pattern of tumour development in carriers of constitutional ring chromosomes. The loss/ rearrangement of chromosomal material in most ring carriers can be ascribed to two different mechanisms. During the initial ring formation, fusion of the distal part of the short arm with the distal part of the long arm may result in loss of material distal to the breakpoints on both chromosome arms. ${ }^{6}$ As a constitutional mutation, this primary loss would be expected to predispose to tumour formation as other germline deletions if a tumour suppressor locus happened to be involved.

A second mechanism for loss or rearrangement of chromosomal material in carriers of ring chromosomes is associated with a generalised mitotic instability of ring formed chromosomes. ${ }^{78}$ Sister chromatid exchange(s) within a monocentric ring chromosome results in the formation of dicentric or interlocked pairs of rings. As a result, a diversity of aneuploid conditions and rearrangements are frequent findings in cells from ring carriers, ranging from gain of chromosomal material to partial or complete loss of the specific chromosome. ${ }^{9}$ The frequency of aneuploid/rearranged cells may vary from chromosome to chromosome, from cell type to cell type, and from person to person, and ring carriers may thus be considered to be unpredictable, but continually evolving, mosaics (dynamic mosiacs). ${ }^{10}$ In contrast to a germline deletion/rearrangement, which will only involve functional loss/alteration of tumour suppressor loci located within the deleted/rearranged area, dynamic mosaicism might have the potential for involving tumour suppressor loci anywhere on the ring chromosome. This type of instability would still be predicted to be associated with the development of chromosome specific types of tumours, but at a lower frequency than observed in germline mutations, since only a fraction of the somatic target cells would be expected to undergo loss/rearrangement of the ring during mitosis.

\section{Methods}

More than 350 cases of published and unpublished constitutional ring chromosomes were included in the search for associated malignancies (Medline 1984-1991) ${ }^{112}$ (table 1).

\section{Results and discussion}

Solid tumours were reported in 10, possibly 11 , cases with constitutional ring chromosomes $^{12-22}$ (table 2), and in all cases the chromosome involved was shown to harbour one or more tumour suppressor genes (table 1).

Furthermore, in those cases with tumours with a mapped predisposition locus (RB1, 
Table 1 Number of reviewed cases with constitutional autosomal ring chromosomes and reported numbers with associated solid tumours.

\begin{tabular}{|c|c|c|c|}
\hline $\begin{array}{l}\text { Ring } \\
\text { chromosome }\end{array}$ & $\begin{array}{l}\text { No of } \\
\text { cases }\end{array}$ & $\begin{array}{l}\text { No with } \\
\text { solid tumour }\end{array}$ & $\begin{array}{c}\text { Chromosome known to harbour tumour } \\
\text { suppressor* }\end{array}$ \\
\hline $\begin{array}{l}1 \\
2 \\
3 \\
4 \\
5 \\
6 \\
7 \\
8 \\
9 \\
10 \\
11 \\
12 \\
13 \\
14 \\
15 \\
16 \\
17 \\
18 \\
19 \\
20 \\
21+\text { GI } \\
22+\text { GII }\end{array}$ & $\begin{array}{r}4 \\
6 \\
4 \\
25 \\
12 \\
16 \\
4 \\
3 \\
13 \\
10 \\
7 \\
5 \\
40 \\
32 \\
15 \\
4 \\
8 \\
48 \\
3 \\
11 \\
41 \\
51\end{array}$ & $\begin{array}{l}1+ \\
3\end{array}$ & $\begin{array}{l}+ \\
+ \\
+ \\
+\end{array}$ \\
\hline Total & 358 & $10(11)$ & \\
\hline
\end{tabular}

* Adapted from reference 1 .

$\uparrow$ Ring structure only inferred indirectly.
10 a candidate for harbouring a locus associated with this type of thyroid tumour. A transforming oncogene has been isolated from several human papillary thyroid carcinomas ${ }^{31}$ and mapped by in situ hybridisation to chromosome region $10 \mathrm{q} 11-\mathrm{q} 12 .{ }^{32}$ Translocations involving chromosome 10 have been described in both papillary carcinoma and follicular adenoma of the thyroid. ${ }^{334}$ Many well differentiated thyroid carcinomas may show admixtures of both papillary and follicular elements, which may suggest a common pathogenetic mechanism, and familial occurrence of papillary carcinoma of the thyroid have been reported, ${ }^{35-37}$ suggesting the involvement of a tumour suppressor gene. Interestingly, a candidate locus for another malignancy of the thyroid, medullary carcinoma of the thyroid, which is a feature of multiple endocrine neoplasia type IIA (MEN2A), has also been mapped to chromosome 10 , within the pericentric region $10 \mathrm{p} 11.2-\mathrm{q} 11.2 .^{3839}$

\section{GERMLINE MUTATIONS OR DYNAMIC SOMATIC} MOSAICISM?

A much lower frequency of retinoblastoma has been observed in subjects with $r(13)$ than in those with interstitial deletions of $13 \mathrm{q} .{ }^{40} \mathrm{Al}-$ though this may be taken as evidence that primary germline deletions involving $R B 1$ are rare in $\mathrm{r}(13)$, we cannot exclude that germline mutations may have occurred in the few cases with $r(13)$ who developed retinoblastoma, since the breakpoints were not mentioned. However, breakpoints have been reported in some of the other rings associated with tumour development (table 2). One was the case with $r(11)$ who developed Wilms' tumour. ${ }^{16}$ Since one of the Wilms' tumour loci maps to the distal part of $11 \mathrm{p} 15,{ }^{25}$ it is possible that this locus might have been deleted during the initial ring formation. However, visible constitutional deletions within $11 \mathrm{p} 15$ have not been reported, providing some support for the involvement of dynamic mosaicism in this case. Also, if the WT1 locus at $11 \mathrm{p} 13^{24}$ was the decisive locus involved in the tumour formation, a secondary ring mediated rearrangement would be the likely mutational mechanism.

Constitutional mosaicism for two rings, one with breakpoint far from the $13 \mathrm{q} 14$ region and one with a breakpoint within the $13 q 14$ region, ${ }^{19}$ suggests that one of the two mutational mechanisms might have been operative in the case with r(13) who developed rhabdomyosarcoma.

The candidate regions on chromosome 10 which have been implicated in rearrangements in thyroid tumours ${ }^{32-34}$ all appear to be far from the terminal breakpoints in the $r(10)$ associated with development of a thyroid tumour. ${ }^{20}$ Thus, ring mediated dynamic mosaicism seems to be the most plausible mutational mechanism in this case.

$R(22), R(17)$, AND NEUROFIBROMATOSIS

In familial retinoblastoma the inherited mutation is a germline mutation of the retinoblas- 
Table 2 Reported tumours or tumour predisposing disorders in cases with constitutional autosomal ring chromosomes.

\begin{tabular}{|c|c|c|c|c|}
\hline \multirow[b]{2}{*}{ Tumour type } & \multirow[b]{2}{*}{ Ring } & \multirow[b]{2}{*}{ Breakpoints } & \multicolumn{2}{|c|}{ Possible mode of mutation } \\
\hline & & & Germline & Dynamic mosaicism \\
\hline $\begin{array}{l}\text { Follicular adenocarcinoma of the thyroid }{ }^{20} \\
\text { Wilms' tumour }^{16} \\
\text { Retinoblastoma }^{13} \\
\text { Retinoblastoma }^{14} \\
\text { Retinoblastoma? }^{15} \\
\text { Rhabdomyosarcoma }^{19} \\
\text { Embryonic sarcoma }^{18} \\
\text { Neurofibromatosis }^{22} \\
\text { Meningioma } \\
\text { Neurofibromatosis }^{21} \\
\text { Neurofibromatosis, intracranial tumour, } \\
\text { testicular seminoma } \\
12\end{array}$ & $\begin{array}{c}10 \\
11 \\
13 \\
13 \\
13 \\
13 \\
D(13) \\
17^{*} \\
22 \\
22 \\
22\end{array}$ & 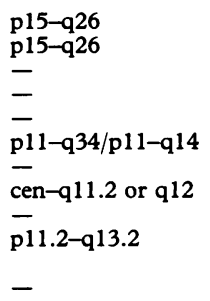 & + & $\begin{array}{l}+ \\
+ \\
+ \\
+\end{array}$ \\
\hline
\end{tabular}

- Breakpoints not determined/mentioned.

* Ring structure only inferred indirectly.

toma gene. Similarly, germline mutations of specific tumour suppressor loci are the likely mutations in other dominantly inherited tumour predisposition disorders like von Recklinghausen neurofibromatosis $(\mathrm{NF} 1)^{41}$ and neurofibromatosis type 2 (NF2). ${ }^{4243}$ Two cases with $r(22)$ have been reported in association with neurofibromatosis. ${ }^{121}$ Because of lack of a family history of NF and lack of other clinical features associated with either NF1 or NF2 (café au lait spots, axillary freckling, Lisch nodules, bilateral acoustic neurinoma), the type(s) of neurofibromatosis in these two cases could not be determined. A candidate locus would be the NF2 locus which is located on chromosome $22 .{ }^{42}{ }^{43}$ However, support for constitutional retainment of the NF2 flanking markers $D 22 S 1$ and $D 22 S 28^{44}$ in one case ${ }^{12}$ and the very distal breakpoints $(22 \mathrm{p} 13 ; 22 \mathrm{q} 13.2)$ in the other $r(22)^{21}$ do not support a ring chromosome associated germline mutation involving the NF2 locus. Thus, more than one NF locus may be associated with chromosome 22 , or the dynamic somatic mosaicism associated with r(22) might be responsible for an aberrant clinical development of NF2 in these two cases.

Dynamic somatic mosaicism was also suggested as a possible mutational mechanism in a sporadic case with late onset (40 years) of NF1, who carried a small, presumably ring chromosome excised from the proximal part of $17 \mathrm{q}^{22}$ where data so far indicate that the NF1 gene has not been disrupted (Andersen, personal communication).

Interestingly, multiple café au lait spots of about $10 \mathrm{~mm}$ in size were reported in the two oldest (10 and 6 years) of the seven cases described with $r(17),{ }^{4546}$ conforming to one of the diagnostic criteria of NF1 (six café au lait macules over $5 \mathrm{~mm}$ in size) in prepubertal persons. ${ }^{47}$ Continued monitoring of $r(17)$ carriers may indicate whether additional signs of NF1 (principally neurofibromas) will develop.

CHROMOSOME 22 AND TESTICULAR CANCER Apart from being associated with the development of meningioma and acoustic neurinomas, chromosome 22 is also the chromosome the most frequently lost in colonic tumours from patients with hereditary polyposis coli. ${ }^{48}$ Thus, chromosome 22 may contain several tumour suppressor genes or the same locus (loci) may be associated with the development of a variety of different tumours. In a previous study of testicular tumours which showed significant loss of heterozygosity for markers on chromosome regions $3 \mathrm{p}$ and $11 \mathrm{p}$ only, chromosome 22 markers were not included..$^{4}$ The development of seminoma in a $r(22)$ carrier $^{12}$ indicates that molecular analysis of testicular tumours with chromosome 22 markers may be worthwhile.

Since the development of cancer is age related and most subjects with rings have been examined cytogenetically in early life because of the associated mental retardation/dysmorphology, it is likely that only a few and predominantly childhood tumours like RB1 and WT have been reported in association with ring chromosomes so far. The subsequent development in young adulthood of meningioma ${ }^{17}$ and testicular cancer ${ }^{12}$ in $r(22)$ carriers years after the initial cytogenetic diagnosis supports this.

It is conceivable that the figures in table 1 proposing a risik for development of tumours in carriers of ring chromosomes harbouring tumour suppressor genes as high as 10 to $14 \%$ is an overestimate owing to ascertainment bias. Still, continuous clinical monitoring of carriers of ring chromosomes, especially of those known to harbour tumour suppressors, seems warranted. An important spin off may be hints of new associations between individual chromosomes and specific types of malignancies, which may then aid in chromosome directed molecular analysis of sporadic tumours.

This study was supported by The Danish Cancer Society, The Norwegian Cancer Society, and The Danish Centre for Human Genome Research.

1 Weinberg R. Tumor suppressor genes. Science 1991 254:1138-46.

2 Knudson AG. Model hereditary cancers of man. Prog Nucleic Acid Res Mol Biol 1973;29:17-25.

3 Cavenee WK, Dryja TP, Phillips RA, et al. Expression of recessive alleles by chromosomal mechanisms in retinoblastoma. Nature 1983;305:779-85.

4 Turleau C, de Grouchy J. Constitutional karyotypes in retinoblastoma. Ophthal Paediatr Genet 1987;8:11-7.

retinoblastoma. Ophthal Paediatr Genet 1987;8:11-7.
5 Motegi T. High rate of detection of $13 q 14$ deletion mosaicism among retinoblastoma patients (using more extensive
is methods). Hum Genet 1982;61:95-7.

6 McGinniss MJ, Kazazian HH, Stetten G, et al. Mechanisms of ring chromosome formation in 11 cases of human ring chromosome 21. Am f Hum Genet 1992;50:15-28.

7 McClintock $\mathrm{B}$. The production of homozygous deficient tissues with mutant characteristics by means of the aberrant mitotic behaviour of ring shaped chromosomes. Genetics 1938;23:315-76.

8 Kistenmacher ML, Punnett HH. Comparative behaviour of ring chromosomes. Am $\mathcal{f}$ Hum Genet 1970;22:304-18. 
9 Wyandt HE. Ring autosomes: identification, familial transmission, causes of phenotypic effects and in vitro mosaicism. In: The cytogenetics of mammalian autosomal rearrangements. New York: Alan R Liss, 1988:667-95.

10 McDermott A, Voyce MA, Romain DJ. Ring chromosome 4. $₹$ Med Genet 1977;14:228-32.

11 Schinzel A. Catalogue of unbalanced chromosomal aberrations in man. Berlin: Walter deGruyter, 1984.

12 Tommerup N, Warburg M, Gieselmann V, Hansen BR, Koch J, Petersen GB. Ring chromosome 22 and neurofibromatosis. Clin Genet (in press)

13 Grace E, Drennan J, Colver D, Gordon RR. The 13q deletion syndrome. $\mathcal{F}$ Med Genet 1971;8:351-7.

14 Diallo JS, Afoutou JM, Balo K. Rétinoblastome: premier cas de chromosome 13 en anneau en afrique noire. Rev Int Trach Pathol Ocul Trop Subtrop Sante Publique 1987; 64:183-6.

15 Lejeune J, Lafourcade J, Berger R, et al. Etude de trois cas de chromosome $\mathrm{D}$ en anneau. Ann Genet (Paris) 1968;11:79-87.

16 Romain DR, Gebbie OB, Parfitt RG, et al. Two cases of ring chromosome 11. ₹ Med Genet 1983;20:380-2.

17 Arinami T, Kondo I, Hamaguchi $H$, Nakajima S. Multifocal meningiomas in a patient with a constitutional ring chromosome 22. $¥ \mathrm{Med}$ Genet 1986;23:178-80.

18 Ayraud N, Szepetowski G, Gares R, Vaillaud JC. Sarcome embryonnaire et chromosome $\mathrm{D}$ en anneau. Ann Genet (Paris) 1970;13:199-200

19 Voullaire LE, Petrovic V, Sheffield LJ, Campbell P. Two forms of ring 13 in a child with rhabdomyosarcoma. $\mathrm{Am} \mathcal{F}$ Med Genet 1991;39:285-7.

20 Sparkes RS, Ling SM, Muller H. Ring 10 chromosome: 46,XX,r10(p15q26). Hum Genet 1978;43:341-5.

21 Duncan AMV, Partington MV, Soudek D. Neurofibromatosis in a man with ring 22: in situ hybridization studies. Cancer Genet Cytogenet 1987;25:169-74.

22 Andersen LB, Tommerup N, Koch J. Formation of a minichromosome by excision of the proximal region of $17 \mathrm{q}$ in a patient with von Recklinghausen neurofibromatosis. patient with von Recklinghausen

23 Yunis JJ, Ramsay N. Retinoblastoma and subband deletion of chromosome 13. Am $\mathcal{Y}$ Dis Child 1978;132:161-3.

24 Riccardi VM, Sujansky E, Smith AC, Francke U. Chromosomal imbalance in the aniridia-Wilms tumour association: $11 \mathrm{p}$ interstitial deletion. Pediatrics 1978;61:604-10.

25 Koufos A, Grundy P, Morgan K, et al. Familial Wiedemann-Beckwith syndrome and a second Wilms tumour locus both map to 11 p15.5. Am f Hum Genet 1989;44:711-9.

26 Zang KD. Cytological and cytogenetical studies on human meningioma. Cancer Genet Cytogenet 1982;6:249-74.

27 Dumanski JP, Rouleau GA, Nordenskjöld M, Collins VP. Molecular genetic analysis of chromosome 22 in 81 cases of meningioma. Cancer Res 1990;50:5863-7.

28 Friend SH, Horowitz JM, Gerber MR, et al. Deletions of a DNA sequence in retinoblastomas and mesenchymal tumours: organization of the sequence and its encoded mours: organization of the sequence and its encoder

29 Weichselbaum RR, Beckett M, Diamond A. Some retinoblastomas, osteosarcomas, and soft tissue sarcomas may blastomas, osteosarcomas, and soft tissue sarcomas may
share a common etiology. Proc Natl Acad Sci USA share a commo

30 Rowe D, Gerrard M, Gibbons B, Malpas JS. Two further cases of $t(2 ; 13)$ in alveolar rhabdomyosarcoma indicating Cancer 1987;56:379-80.

31 Fusco A, Grieco M, Santoro $M$, et al. A new oncogene in human thyroid papillary carcinomas and their lymphnodal metastases. Nature 1987;328:170-2.

32 Radice P, Donghi R, Sozzi G, et al. DNA sequence linked to the human papillary thyroid carcinoma (PTC) oncogene map to chromosome 10q11-q12 and identify TaqI and HincII RFLPs. HGM10 (A2599). Cytogenet Cell Genet 1989;51:1062.

33 Antonini P, Venuat AM, Linares G, Caillou B, Berger R, Parmentier C. A translocation $(7 ; 10)(\mathbf{q} 35 ; \mathrm{q} 21)$ in a differentiated papillary carcinoma of the thyroid. Cancer Genet Cytogenet 1989;41:139-44.

34 Bartnitzke S, Herrmann ME, Lobeck $H$, Zuschneid W, Neuhaus P, Bullerdiek J. Cytogenetic findings on eight follicular thyroid adenomas including one with a t $(10 ; 19)$. Cancer Genet Cytogenet 1989;39:65-8.

35 Lote K, Andersen K, Nordal E, Brennhovd IO. Familial occurrence of papillary thyroid carcinoma. Cancer 1980;46:1291-7.

36 Phade VR, Lawrence WR, Max MH. Familial papillary carcinoma of the thyroid. Arch Surg 1981;116:836-7.

37 Stoffer SS, Van Dyke DL, Bach JV, Szpunar W, Weiss L. Familial papillary carcinoma of the thyroid. $A m \mathcal{F} M e d$ Fenet 1986;25:775-82.

38 Mathew CGP, Chin KS, Easton DF, et al. A linked genetic marker for multiple endocrine neoplasia type $2 \mathrm{~A}$ on chromosome 10. Nature 1987;328:527-8.

39 Simpson NE, Kidd KK, Goodfellow PJ, et al. Assignment of multiple endocrine neoplasia type $2 \mathrm{~A}$ to chromosome 10 by linkage. Nature $1987 ; 328: 528-30$.

40 Taylor AI. Dq-, Dr and retinoblastoma. Humangenetik 1970;10:209-17.

41 Buchberg AM, Cleveland LS, Jenkins NA, Copeland NG. Sequence homology shared by neurofibromatosis type-1 gequence and IRA-1 and IRA-2 negative regulators of the gene and IRA-1 and IRA-2 negative regulators of
RAS cyclic AMP pathway. Nature 1990;347:291-4.

42 Seizinger BR, Martuza RL, Gusella JF. Loss of genes on chromosome 22 in tumourigenesis of human acoustic neuroma. Nature 1986;322:644-7.

43 Seizinger BR, Rouleau G, Ozelius LJ, et al. Common pathogenetic mechanism for three tumour types in bila-

44 Rouleau GA, Seizinger BR, Wertelecki W, et al. Flanking markers bracket the neurofibromatosis type $2(\mathrm{NF} 2)$ gene on chromosome 22. Am f Hum Genet 1990;46:323-8.

45 Ono K, Suzuki Y, Fujii I, Takeshita K, Arima M, Nakagome Y. A case of ring chromosome E17:46,XX,r(17)(p13 $\rightarrow$ q25). Fpn f Hum Genet 1974;19:235-42.

46 Qazi QH, Madahar C, Kanachanapoomi R, Giridharan R, Beller E. Ring chromosome 17 in a mentally retarded boy Ann Genet (Paris) 1979;22:234-8.

47 Stumpf DA, Alksne JF, Annegers JF, et al. Neurofibromatosis. NIH Consensus Development Conference Statement 6, 1987, No 12. Arch Neurol 1988;45:575.

48 Okamoto M, Sasaki M, Sugio K, et al. Loss of constitutional heterozygosity in colon carcinoma from patients with familial polyposis coli. Nature 1990;331:273-7.

49 Lothe RA, Fossa SD, Stenwig AE, et al. Loss of $3 p$ or $11 p$ alleles is associated with testicular cancer tumours. Genomics 1989;5:134-8. 